\title{
Quantitative high-resolution warm season rainfall recorded in varved sediments of Lake Oeschinen, northern Swiss Alps: calibration and validation AD 1901-2008
}

\author{
Benjamin Amann • Fabian Mauchle • \\ Martin Grosjean
}

Received: 7 May 2013/ Accepted: 18 December 2013/Published online: 24 January 2014

(C) Springer Science+Business Media Dordrecht 2014

\begin{abstract}
High-resolution, well-calibrated records of lake sediments are critically important for quantitative climate reconstructions, but they remain a methodological and analytical challenge. While several comprehensive paleotemperature reconstructions have been developed across Europe, only a few quantitative highresolution studies exist for precipitation. Here we present a calibration and verification study of lithoclastic sediment proxies from proglacial Lake Oeschinen $\left(46^{\circ} 30^{\prime} \mathrm{N}, 7^{\circ} 44^{\prime} \mathrm{E}, 1,580 \mathrm{~m}\right.$ a.s.l., north-west Swiss Alps) that are sensitive to rainfall for the period $\mathrm{AD}$ 1901-2008. We collected two sediment cores, one in 2007 and another in 2011. The sediments are characterized by two facies: (A) mm-laminated clastic varves and (B) turbidites. The annual character of the laminae couplets was confirmed by radiometric dating $\left({ }^{210} \mathrm{~Pb}\right.$,
\end{abstract}

B. Amann · M. Grosjean

Oeschger Center for Climate Change Research,

University of Bern, Bern, Switzerland

e-mail: martin.grosjean@oeschger.unibe.ch

B. Amann ( $\square)$

Institute of Geography, University of Bern, Erlachstrasse

9a T3, 3012 Bern, Switzerland

e-mail: benjamin.amann@giub.unibe.ch

F. Mauchle

MeteoSwiss, Krähbühlstrasse 58, Zurich, Switzerland

e-mail: fabian.mauchle@meteoswiss.ch
${ }^{137} \mathrm{Cs}$ ) and independent flood-layer chronomarkers. Individual varves consist of a dark sand-size springsummer layer enriched in siliciclastic minerals and a lighter clay-size calcite-rich winter layer. Three subtypes of varves are distinguished: Type I with a 1-1.5 mm fining upward sequence; Type II with a distinct fine-sand base up to $3 \mathrm{~mm}$ thick; and Type III containing multiple internal microlaminae caused by individual summer rainstorm deposits. Delta-fan surface samples and sediment trap data fingerprint different sediment source areas and transport processes from the watershed and confirm the instant response of sediment flux to rainfall and erosion. Based on a highly accurate, precise and reproducible chronology, we demonstrate that sediment accumulation (varve thickness) is a quantitative predictor for cumulative boreal alpine spring (May-June) and spring/summer (May-August) rainfall $\left(\mathrm{r}_{\mathrm{MJ}}=0.71, \mathrm{r}_{\mathrm{MJJ}}=0.60, p<0.01\right)$. Bootstrap-based verification of the calibration model reveals a root mean squared error of prediction $\left(\right.$ RMSEP$_{\mathrm{MJ}}=32.7 \mathrm{~mm}, \quad$ RMSEP$\left._{\mathrm{MJJA}}=57.8 \mathrm{~mm}\right)$ which is on the order of $10-13 \%$ of mean $\mathrm{MJ}$ and MJJA cumulative precipitation, respectively. These results highlight the potential of the Lake Oeschinen sediments for high-resolution reconstructions of past rainfall conditions in the northern Swiss Alps, central and eastern France and south-west Germany.

Keywords Lake sediments - Clastic varves · Sedimentology $\cdot$ Limnogeology $\cdot$ Climate change $\cdot$ Paleoclimatology 


\section{Introduction}

High-resolution quantitative reconstructions of climate variables are crucial for understanding Earth system variability, assessing the sensitivity of the climate to natural and anthropogenic forcing, and thus reducing uncertainty in future climate projections (Hegerl et al. 2006; Mann et al. 2008; Villalba et al. 2009; PAGES $2 \mathrm{k}$ Consortium 2013). Data from natural paleoclimatic archives are one of the few means, together with documentary data, to obtain this information beyond the instrumental period.

In this context, lake sediments are valuable natural paleoclimatic archives due to their potential to preserve climate variability through very long times and at a high temporal resolution (Zolitschka 1996; Pienitz and Lotter 2009). This is particularly true for varved lake sediments that contain records of past climate at annual resolution and with high chronological precision for millennial to Holocene scales (Zolitschka 2007). Although the scientific community has greatly extended worldwide knowledge about lake sediments and varve records (Ojala et al. 2012), very few have actually generated quantitative very highresolution multi-century to millennial long climate reconstructions (Hughen et al. 2000; Moore et al. 2001; Kalugin et al. 2007; McKay et al. 2008; Trachsel et al. 2008, 2010; von Gunten et al. 2009; LarocqueTobler et al. 2010; Larocque-Tobler et al. 2011; Stewart et al. 2011; Elbert et al. 2012; Saunders et al. 2013; PAGES 2 K Consortium 2013).

Moreover, while considerable advances have been made in developing temperature reconstructions in Europe and the Alps for the last 1,000 years (Trachsel et al. 2012; PAGES $2 \mathrm{k}$ Consortium 2013), very little is known about past precipitation (Casty et al. 2005; Pauling et al. 2006; Trachsel et al. 2008; Büntgen et al. 2011). However, precipitation regimes are fundamental for understanding the variability of the water cycle, which is arguably as important as fluctuations in temperature. In many ways the water cycle is even and often more relevant for society, especially in sensitive Alpine areas, notably with regard to flood extremes (Pfister 1999).

This data scarcity is mainly due to the difficulties in obtaining robust, well calibrated and quantified long time series, preferably annually resolved, of reconstructed climate variables from different archives, including lake sediments.
This paper reports the varve thickness-warm season precipitation calibration and validation (AD 1901-2008) of a varve record from proglacial Lake Oeschinen in the northern Swiss Alps. Leemann and Niessen (1994) previously reported a mixed temperature and precipitation signal recorded in the sediments of this lake. In their study they found a correlation of $r=0.45$ between varve thickness and mean summer air temperature for observations between AD 1962-1982 ( $\mathrm{n}=21)$, and a strong covariance with summer precipitation. Here, we show on a longer record $(n=108)$ that Lake Oeschinen's sediments record a warm season precipitation signal and how temperature modulates the sediment-precipitation relationship, in particular for very cold years (AD 1900-1915) and the period in the 1960-1970s investigated by Leemann and Niessen (1994).

To achieve this aim, we first interpret the hydroclimatic varve formation process by comparing sediment thin sections with delta fan surface samples, sediment trap and meteorological data. We then provide a set of high-resolution sediment proxy data (facies, mineralogical and geochemical sediment properties) with a robust chronology for the calibration period AD 1901-2008. Finally we test the statistical relationship between the precipitation regime and the varve properties, and its potential for the extension of the varve record beyond the instrumental period.

Study site

Lake Oeschinen $\left(46^{\circ} 30^{\prime} \mathrm{N}, 7^{\circ} 44^{\prime} \mathrm{E}\right)$ is a proglacial lake $\left(1.18 \mathrm{~km}^{2}\right)$ located in the northern Swiss Alps, $55 \mathrm{~km}$ south of Bern at an altitude of 1,580 m (Fig. 1a). The lake is oligotrophic, dimictic, thermally stratified in summer, and ice-covered from December through early May. The lake basin, formed by a Holocene rockslide (9.5 cal kyrs BP), is topographically closed and has an underground outflow through the rockslide body (Niklaus 1967; Leemann and Niessen 1994). Annual lake level fluctuations average $12 \mathrm{~m}$ from a minimum of a 44-m water depth measured in late winter to a maximum depth of $56 \mathrm{~m}$ in summer.

Bedrock in the catchment is mostly composed of Mesozoic limestone of Jurassic and Cretaceous age (Fig. 1a, in blue and green). The northern part of the catchment however, includes two important belts of Tertiary Flysch deposits (Fig. 1a, in yellow), which 
a

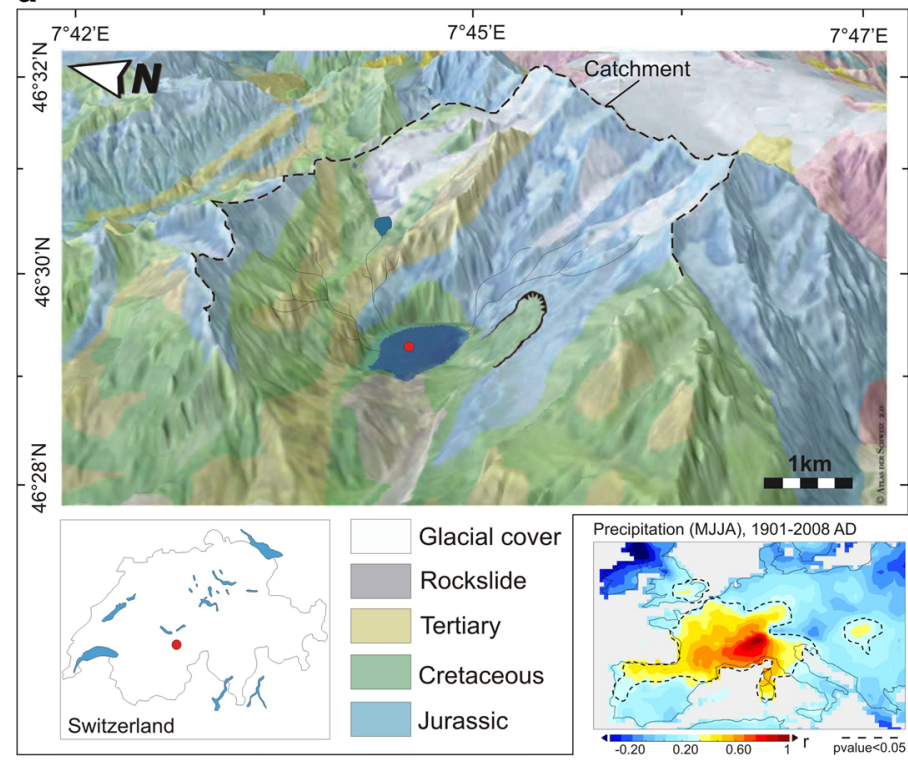

b

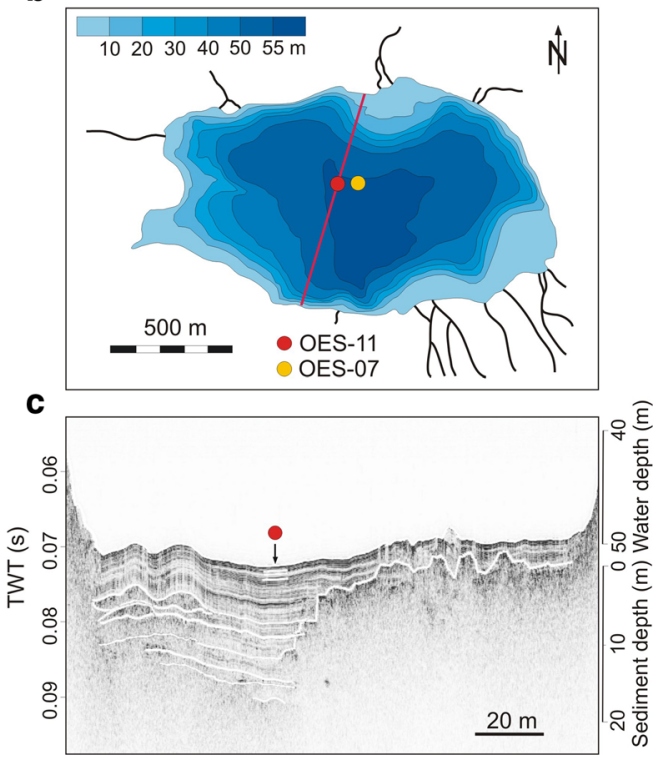

Fig. 1 Characteristics of Lake Oeschinen: a location in the Bernese Swiss Alps, topographical and geological settings of the catchment area, spatial correlation maps for warm season precipitation; $\mathbf{b}$ bathymetric map of the lake basin adapted from
Leemann and Niessen (1994) showing the two coring sites; c details of the south-north seismic profile with the location of core OES-11 (courtesy: A. Gilli ETH Zurich) consist of erodible sandstones with abundant siliciclastic minerals (Suchy et al. 1997). Mountains in the catchment area $\left(22 \mathrm{~km}^{2}\right)$ reach $3,660 \mathrm{~m}$ and glacier cover accounts for about $30 \%$ of the watershed (reference year 1993). Hydro-geologically, the catchment can be subdivided into three watershed systems separating the creeks of the north from creeks of the south and those from the north-east. Geological properties of these watersheds are reported in Table 1. A small moraine-dammed proglacial lake was formed in the late 1950 s $(2,148 \mathrm{~m}$ a.s.l., Fig. 1a) after the Blüemlisalp Glacier retreated. It now acts as a hydrological intermediate between the largest glacier of the catchment and Lake Oeschinen.

Climate variability in the Bernese northern Swiss Alps is influenced by both Atlantic and continental regimes. The North Atlantic Oscillation (NAO) is the dominant climate mode driving these influences, where the Azores High and surface heat lows over the Eurasian land mass alternately influence the variability of the summer system (Wanner et al. 1997; Casty et al. 2005).

Monthly mean temperature data are available from the meteorological station of Adelboden $(1,320 \mathrm{~m}$ a.s.1., $13 \mathrm{~km}$ west of Lake Oeschinen) and range from $-2.9^{\circ} \mathrm{C}$ in January to $15.0^{\circ} \mathrm{C}$ in July (AD 1900-2009; MeteoSwiss). Precipitation data over the same period are available from the meteorological station of Kandersteg (1,176 m a.s.l.), located $3 \mathrm{~km}$ west and downhill of the lake. They display unimodal summer-winter cycles typical of the northern Alps (Brunetti et al. 2006) with a total annual precipitation of $1,173 \mathrm{~mm}$. Monthly mean precipitation ranges from $69 \mathrm{~mm}$ in February to a peak of $142 \mathrm{~mm}$ in July. Local thunderstorms are relatively frequent and critical because they occasionally cause numerous and severe damage, notably in the vicinity of the Kander River that flows downstream Lake Oeschinen (SchmockerFackel and Naef 2010).

The CRU TS 3.0 precipitation data (Mitchell and Jones 2005; grid cell $46.5-47^{\circ} \mathrm{N}$ and $7.5-8^{\circ} \mathrm{E}$ ) are significantly correlated with the meteorological station of Kandersteg $\left(\mathrm{r}_{\mathrm{MJJA}}=0.55, \quad p<0.05\right.$, 1901-2008). Spatial correlation maps with the CRU TS gridded data show that warm season precipitation in the area of Lake Oeschinen is representative for the western Alps including Switzerland, middle and eastern France and southern Germany (Fig. 1a). 


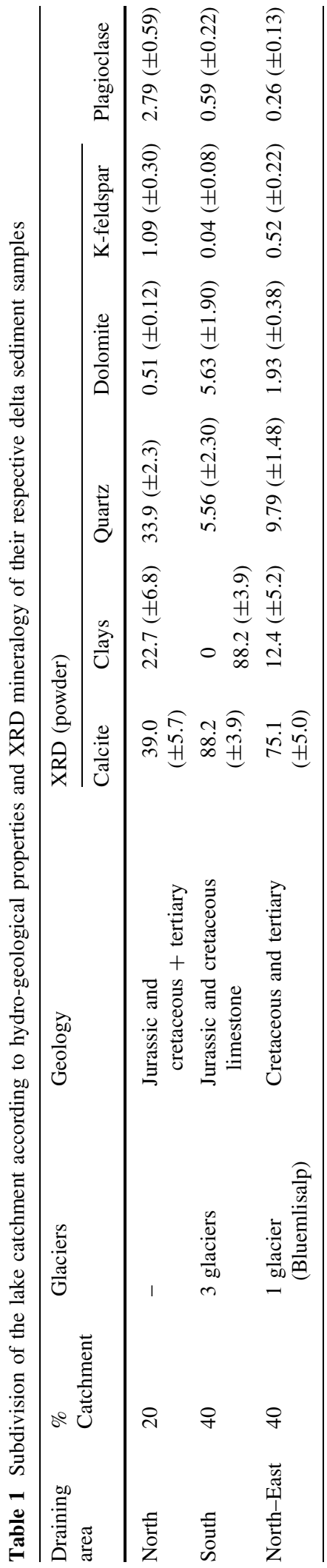

\section{Materials and methods}

Sedimentation process study

Delta fan sediment samples were collected around the shoreline of Lake Oeschinen, homogeneously powdered and analysed by X-ray diffraction (XRD, Philips PW $3710,0.02^{\circ} 2 \theta$ resolution) for quantitative determination of mineral compositions. Results are expressed as weight percent and grouped according to the hydro-geological sub-division of the lake catchment.

Two sediment traps (cylindrical, $\varnothing=9 \mathrm{~cm}$ ) were deployed at $4 \mathrm{~m}$ above the lake floor from May 2007 to October 2008 to monitor seasonal sediment supply into the lake at the coring site. Trapped material was freeze-dried and weighed to calculate dry mass accumulation rates (MAR) over the seasonal intervals of sampling. The lithogenic fractions of the samples were also analysed for particle size distribution using laser diffraction (Malvern Mastersizer 2000S) after removal of organic matter (with $\mathrm{H}_{2} \mathrm{O}_{2}$ ) and biogenic opal (with $\mathrm{NaOH}$ ).

Sediment coring and processing

Two short sediment cores were recovered in October 2007 (UWITEC freezing corer, $1 \mathrm{~m}$ long; core OES07) and in August 2011 (UWITEC gravity corer, $87 \mathrm{~cm}$ long; core OES-11) from Lake Oeschinen. The choice of the coring sites was based on bathymetric and seismic surveys (Fig. 1b, c). In the laboratory, cores were split lengthwise, described and photographed. Both cores were stratigraphically correlated with turbidite layers and laminae couplets. While thin sections and laminae counts were made on both cores, OES-07 was used for radiometric chronology measurements, and OES-11 was sampled to develop the multi-proxy data set with destructive analytical techniques.

Thin sections were taken from overlapping sediment slabs $(7 \times 1.5 \times 0.5 \mathrm{~cm})$ using freeze-drying and resin-epoxy embedding techniques (Lamoureux 2001). Laminae identification and a master chronology were generated by collating and merging opticalmicroscopy pictures (magnification $\times 10$ ) of the thin sections. The thickness of lamina couplets was semiautomatically measured using the software package WinGeol Lamination Tool (0.01-mm resolution; 
Meyer et al. 2006). Varves were counted three times independently by two analysts. Varve counting errors were assessed from the standard deviation of the different chronologies.

To corroborate the annual nature of laminae couplets, core OES-07 was stratigraphically sampled with spacing from 0.2 to $1.9 \mathrm{~cm}$ (2-3 years intervals) according to homogeneous sedimentary facies (Arnaud et al. 2002). Samples were analysed for ${ }^{226} \mathrm{Ra},{ }^{210} \mathrm{~Pb}$ and ${ }^{137}$ Cs by Gamma-ray spectrometry (EAWAG, Duebendorf). Unsupported ${ }^{210} \mathrm{~Pb}$ was calculated by the levelby-level method and turbidites were removed from the ${ }^{210} \mathrm{~Pb}_{\text {unsupported }}$ profile (Arnaud et al. 2002). We used the Constant Rate of Supply model (CRS; Appleby 2001), unconstrained and constrained by the AD $1963{ }^{137} \mathrm{Cs}$ peak, to convert ${ }^{210} \mathrm{~Pb}$ activities into numerical sediment ages.

The varve chronology inferred from core OES-11 was validated by the comparison between turbidite layers and $\mathrm{HQ}>10$ flood events (discharges larger than high-probability flood events of a 10-year return period) documented in the Kander River in AD 1930, 1944, 1955, 1968, 1987 and 1999 (Schmocker-Fackel and Naef 2010). The consistency of the two chronologies from OES-07 to OES-11 was assessed by comparing the cumulative sedimentation rates from the two cores.

To produce the multi-proxy data set, individual laminae were carefully scraped from the fresh core OES-11. Subsamples were analysed for water content, organic carbon (OC), calcite content and particle size distribution. $\mathrm{OC}$ and calcite contents were derived from loss on ignition at $550{ }^{\circ} \mathrm{C}\left(\mathrm{LOI}_{550}\right)$ and $950{ }^{\circ} \mathrm{C}$ $\left(\mathrm{LOI}_{950}\right)$ respectively. Temperature and time of sample exposure were set following Heiri et al. (2001). The residual after $\mathrm{LOI}_{950}$ is summarized as the siliciclastic fraction (mainly quartz, feldspars and clay minerals).

Varve thicknesses were then converted into annual mass accumulation rate (MAR) after Niessen et al. (1992):

$$
\begin{aligned}
& \text { MAR }=\mathrm{s} * \rho_{\mathrm{s}} *(1-\phi) \\
& \begin{aligned}
\phi & =\mathrm{w} * \rho_{\mathrm{s}} /\left(\mathrm{w} * \rho_{\mathrm{s}}+(1-\mathrm{w}) * \rho_{\mathrm{w}}\right)=\text { porosity } \\
\rho_{\mathrm{s}} & =\mathrm{W}_{\mathrm{D}} /\left(\Pi * \mathrm{r}^{2} * \mathrm{~S}\right) \\
& =\text { dry bulk density of sediments }\left(\mathrm{g} \mathrm{cm}^{-3}\right)
\end{aligned}
\end{aligned}
$$

where $s$ is the thickness of the laminae $(\mathrm{cm}), \rho_{\mathrm{w}}$ is the pore-water density $\left(1.0 \mathrm{~g} \mathrm{~cm}^{-3}\right)$, w is the water content (\%), $\mathrm{W}_{\mathrm{D}}$ is the dry sample mass, $\mathrm{S}$ is the sample width and $\mathrm{r}$ is the radius of the coring tube $(2.9 \mathrm{~cm})$. Fluxes $\left(\mathrm{g} \mathrm{cm}^{-2}\right.$ year $\left.^{-1}\right)$ of OC, calcite and siliciclastics were calculated by multiplying the component concentrations with MAR.

\section{Statistics}

Annual lake sediment data were also 3-year triangular filtered prior to calibration with meteorological data. This accounts for errors in the sampling of individual varves and for dating uncertainties while still allowing a high number of independent observations (degrees of freedom; Kamenik et al. 2009; von Gunten et al. 2012). Pearson correlations were developed between all analysed proxies and meteorological data, and statistical calibrations were performed using Ordinary Least-Squares (OLS) regression model (inverse regression). Each proxy was correlated in a matrix with individual monthly and 2-12 months means of temperature (monthly mean, $\max$ and $\min$ ) and precipitation (mean and cumulative) at both annual and 3-year filtered resolutions. The probability values ( $p$ ) were corrected for serial autocorrelation and multiple testing (de Jong and Kamenik 2011). As shown in the section below, varve thickness was used as the best predictor for warm season precipitation. Since both time series showed a significant increase in the variance after AD 1950 we did not use the split period approach (von Gunten et al. 2012) to validate the calibration model. Instead, the root mean squared error of prediction (RMSEP) was calculated using the bootstrap cross-validation method (Birks 2005).

\section{Results}

Hydrological and geological influences on sediment supply

The hydro-geological properties of the three watersheds around Lake Oeschinen are clearly reflected in the mineralogy of the creek deltas (Table 1). Fractured and loose sediments eroded from the northern Flysch catchment are characterized by a high proportion of quartz (34\%) and clay minerals (23\%, mainly illite and chlorite), while calcite composes $39 \%$ of the sample mass. In contrast, delta fan sediments related to the southern glaciated catchment (compact limestone) 
are mainly composed of calcite (88\%) without any clay minerals and only $6 \%$ of quartz. The third group of delta fan sediments characterizes particles eroded from the north-eastern drainage area. This zone is influenced by both the Blüemlisalp glacier (Cretaceous) and runoff from the north (Tertiary and Cretaceous). Accordingly, the mineralogy shows a mixed signal, with $75 \%$ of calcite, $10 \%$ of quartz and $12 \%$ of clay minerals. Small proportions of dolomite $(<5 \%)$, K-feldspar $(<2 \%)$ and plagioclase $(<3 \%)$ typify the entire catchment.

Figure 2a depicts the sequential fluxes of total dry mass and mean grain size of particles trapped $4 \mathrm{~m}$ above lake floor between May 2007 and October 2008. The flux of particles varied from $0.1 \mathrm{mg} \mathrm{cm}^{-2} \mathrm{day}^{-1}$ of very fine particles $(4 \mu \mathrm{m})$ recorded in autumn (SeptNov 2007) to a maximum of $2.1 \mathrm{mg} \mathrm{cm}^{-2} \mathrm{day}^{-1}$ with grains of $8 \mu \mathrm{m}$ recorded in spring/early summer (MayJuly 2007). The flux of particles stays high in summer (July-September 2007) with $1.9 \mathrm{mg} \mathrm{cm}^{-2} \mathrm{day}^{-1}$ and mean grain size is $11 \mu \mathrm{m}$. A pure winter signal could not be recorded because sampling was possible only after the onset of snow melt and ice out in June 2008. Thus the relatively high winter sedimentation rate $\left(1.1 \mathrm{mg} \mathrm{cm}^{-2}\right.$ day $\left.^{-1}\right)$ is most likely influenced by early spring snowmelt. Similarly, the last sampling interval (July-October 2008) integrated both summer and early autumn, with a particle flux of $1.5 \mathrm{mg} \mathrm{cm}^{-2}$ day $^{-1}$.

The distribution of sediment particle flux over the period of investigation (2007-2008) reveals fairly close patterns with monthly averaged precipitation (Fig. 2a). Maximum rainfall is observed from May to July $(215 \mathrm{~mm})$ and slightly decreases in summer $(180 \mathrm{~mm})$, while autumn records a minimum of $68 \mathrm{~mm}$. Averaged precipitation also mirrors the flux distribution for the last two sampling periods, with 78 and $138 \mathrm{~mm}$ obtained in June and October 2008, respectively. Such patterns cannot clearly be detected when comparing with monthly averaged temperature.

A similar methodology was applied to the sediment trap data recorded in 1991 by Leemann and Niessen (1994). Results in sedimentation rates during the period of investigation also show good agreements with monthly-averaged precipitation measured in Kandersteg rather than with temperature (Fig. 2b).

Qualitative seasonal differences are also observed in the mineralogy of trapped particles (Fig. 2c). Increased proportions of both quartz and clay minerals (illite and chlorite, indicative of the northern Flysch catchment) are found during the progression of summer (from blue to green curve; Fig. 2c). In contrast, particles trapped in autumn (orange curve) and winter (red curve) are characterized by higher proportions of calcite $(+40 \%)$ and low amounts of clay minerals.

\section{Sediment analysis}

Sediments recovered from both cores of Lake Oeschinen consist mainly of light- to dark-grey (Munsell colour: $2.5 \mathrm{Y}-6 / 1$ to $2.5 \mathrm{Y}-4 / 1$, respectively) rhythmically laminated mineroclastic material with low OC (mean $1.98 \%$ ).

The thin sections revealed that the cores are composed of two sediment facies (Fig. 3): lamina couplets (Facies A), intercalated by several graded units interpreted as turbidite layers (Facies B). Facies A alternately comprises sandy and clay-rich laminae with a systematic fining upwards and an average thickness of $3.22 \mathrm{~mm}$. Facies A exhibits three sub-types differing in their internal structure: Type I is characterized by very thin $(1-1.5 \mathrm{~mm})$ fining upward sequences and accounts for $31 \%$ of the core. Type II is thicker $(>3 \mathrm{~mm})$, comprises coarser particles and is the most abundant type found through the whole section (48\%, Fig. 6c). Type III is composed of multiple internal microlaminations and accounts for $21 \%$. Conversely, Facies B shows high sedimentation $(>7 \mathrm{~mm})$, with often coarse (sand) basal layers and modal grain sizes ranging from coarse silt to sand (20-105 $\mu \mathrm{m}$, respectively).

\section{Chronology}

Unsupported ${ }^{210} \mathrm{~Pb}$ activity exponentially decreased from the top of core OES-07 downwards (Fig. 4a). ${ }^{137} \mathrm{Cs}$ first appeared at $32 \mathrm{~cm}$ (start of ${ }^{137} \mathrm{Cs}$ fallout, AD 1954) with a maximum peak measured at $28 \mathrm{~cm}$ $\left({ }^{137} \mathrm{Cs}\right.$ peak AD 1963). The minor ${ }^{137} \mathrm{Cs}$ peak at $13 \mathrm{~cm}$ is attributed to the AD 1986 Chernobyl fallout.

The overall chronology inferred from laminae counts on core OES-07 is consistent with the radiometric chronology $\left({ }^{210} \mathrm{~Pb}-\mathrm{CRS}\right.$ model constrained with the AD $1963{ }^{137} \mathrm{Cs}$ peak), with the ${ }^{137} \mathrm{Cs}$ markers and AD 1987 historical flood (Fig. 4a). The unconstrained CRS model reveals an age difference of 2 years for AD $1963(< \pm 1 \sigma)$ as compared with the constrained CRS model. Hence, laminae couplets 
a
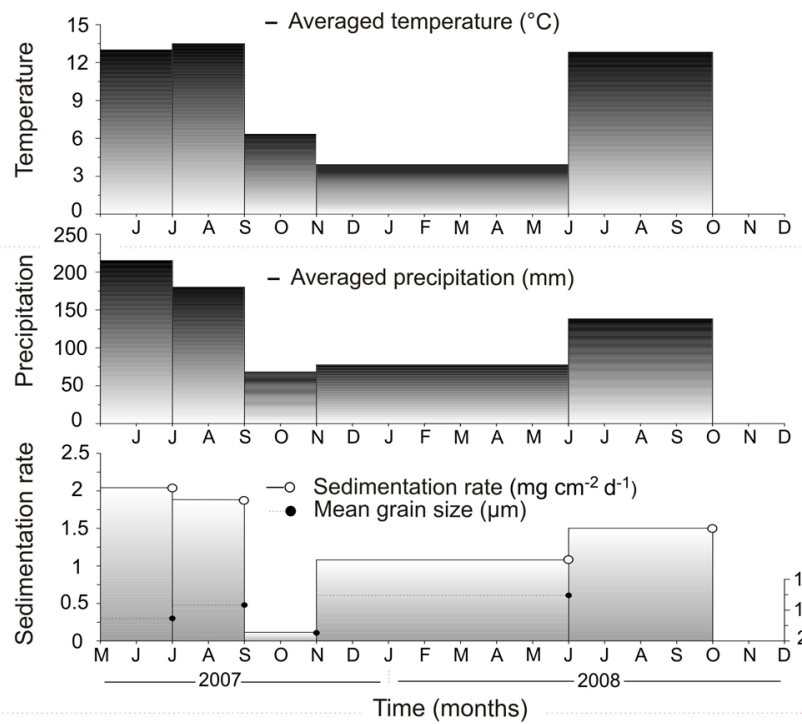

C

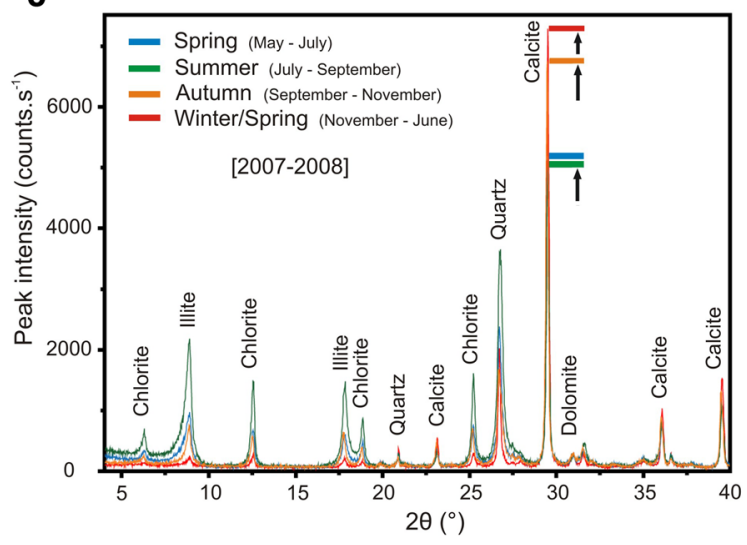

Fig. 2 Sediment trap properties: a comparison of sediment mass accumulation rate and mean grain size with precipitation and temperature through the period 2007-2008; b comparison between reported sediment accumulation rate measured in 1991

(Facies A) are considered as annual varves. Note that the varves in the uppermost part of core OES-07 are poorly preserved and could not be reliably counted (Fig. 4a).

The independent varve counting on the top $50 \mathrm{~cm}$ of core OES-11 (Fig. 4b) indicates an age of 111 years (AD 1900-2011). This age-depth model is verified by six turbidite layers corresponding to high-flood events (HQ $>10)$ in the region of the Kander River in AD 1930, 1944, 1955, 1968, 1987 and 1999. The cumulative counting error stays below \pm 3 years from the top of the core to AD 1920, but reaches a maximum of \pm 5.2 years around AD 1900 . b
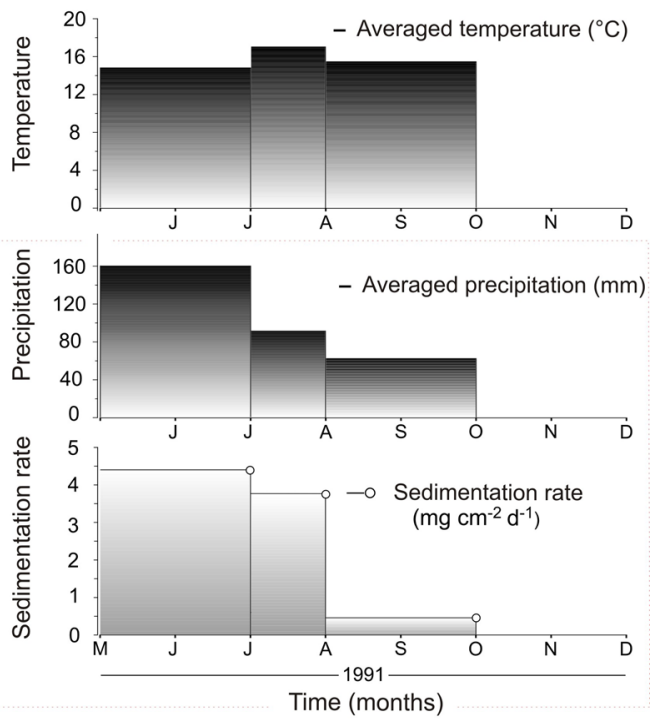

by Leemann and Niessen (1994) and monthly-averaged precipitation and temperature; c qualitative X-ray diffract gram showing the seasonally-distinct mineralogy of the trapped particles

Figure $4 \mathrm{c}$ shows the relationship between the sedimentation rates of the two cores. This relationship exhibits almost no deviation from the 1:1 line and indicates a high reproducibility of the chronology and the varve thickness in both cores $\left(r^{2}=0.99\right)$.

Lithology and physical sediment parameters

Figure 5 summarizes the time series of the proxy data from core OES-11 after removal of the turbidite layers (Facies B). These sediment parameters comprise the water content, the analysis of the grain size, the sedimentary rock type, MAR and the varve thickness. 
Facies A

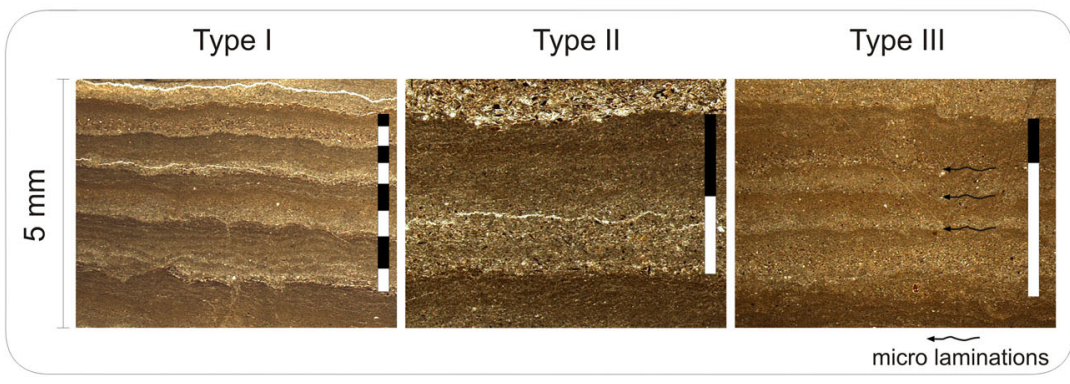

Facies B

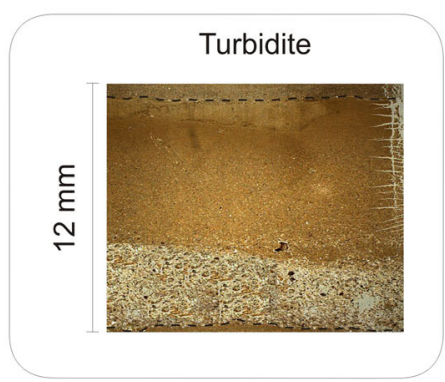

Fig. 3 Photomicrographs of the different sediment facies types. Facies A: the laminae couplets present three different sub-type internal structures. The white and black boxes represent spring- summer (silt to sand) and winter (clay-size particles) accumulation respectively. Facies B: a typical high-sedimentation turbidite layer
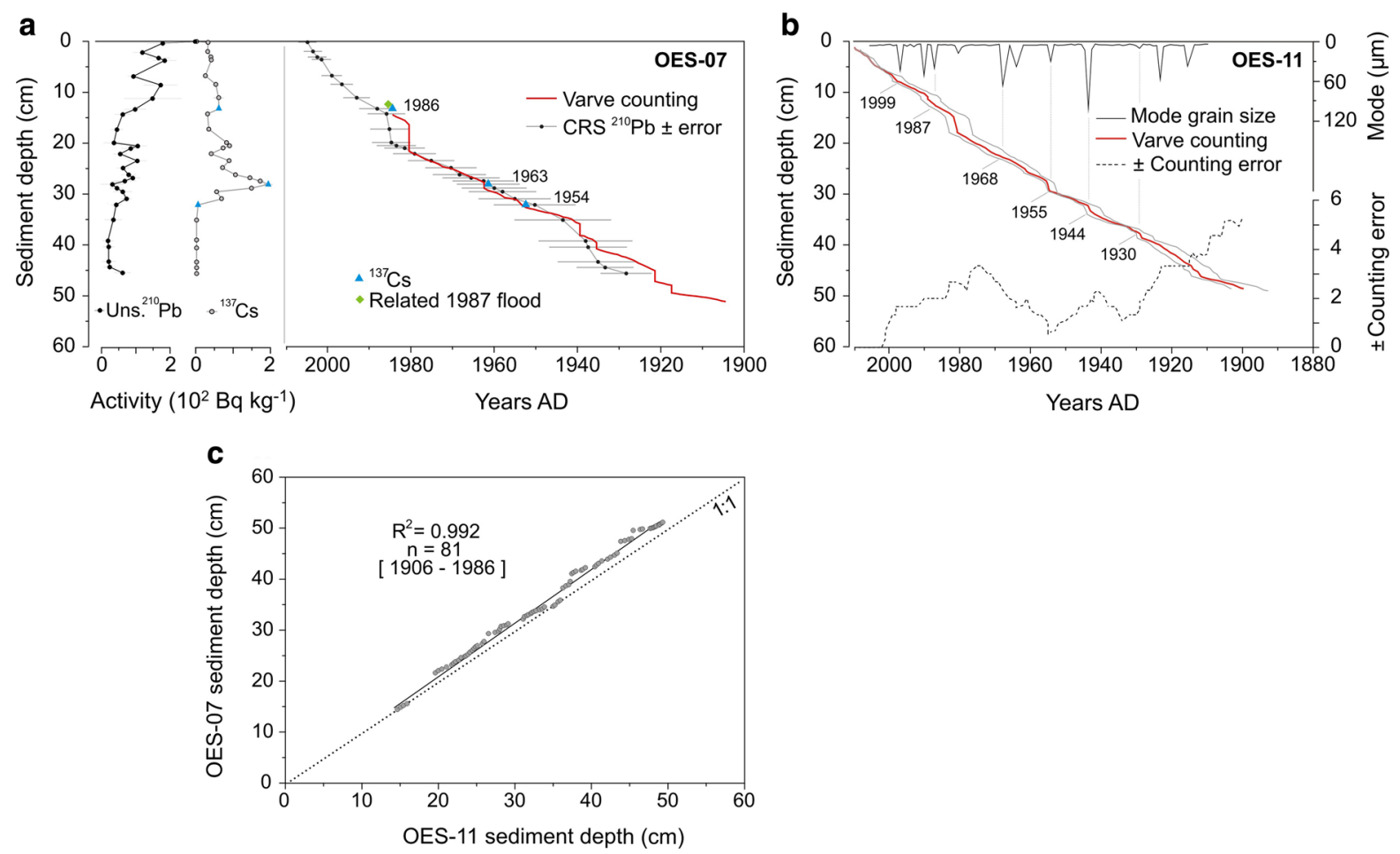

Fig. 4 Sediment chronologies: a downcore activities of unsupported ${ }^{210} \mathrm{~Pb}$ and ${ }^{137} \mathrm{Cs}$ for OES-07, and comparison between the ${ }^{210} \mathrm{~Pb}$-CRS model constrained with the AD 1963-radiocesium peak and varve counting; $\mathbf{b}$ varve ages with counting errors for

The water-content profile presents values between 28.6 and $35 \%$ with minor fluctuations. Mean grain size values are around $25 \mu \mathrm{m}$ and fluctuate considerably. A minimum of $9.5 \mu \mathrm{m}$ is found in $\mathrm{AD} 1910$, while a maximum of $44.4 \mu \mathrm{m}$ is observed for the year AD 1983. The ${ }^{\mathrm{wt}}$ clay/ $/{ }^{\mathrm{wt}}$ sand proportion stays fairly stable from AD 1915 onwards with a mean ratio of 1.8 . In contrast, a
OES-11. The dates report the consistency between turbidites, high modal grain size and documented floods in 1930, 1944, 1955, 1968, 1987, 1999 (Schmocker-Fackel and Naef 2010); c correlation of the sedimentation rates from the two cores

sharp and obvious increase of this ratio occurs between AD 1906 and AD 1914 with the extreme value of 71.8 recorded in $\mathrm{AD}$ 1912, indicating a virtual absence of sand-sized particles during this time. Component flux profiles display a high variability with no apparent trends; mean values of $4.47 \mathrm{mg} \mathrm{cm}^{-2}$ year $^{-1}$ for OC, $143 \mathrm{mg} \mathrm{cm}^{-2}$ year $^{-1}$ for calcite, and $79.1 \mathrm{mg} \mathrm{cm}^{-2}$ year $^{-1}$ 


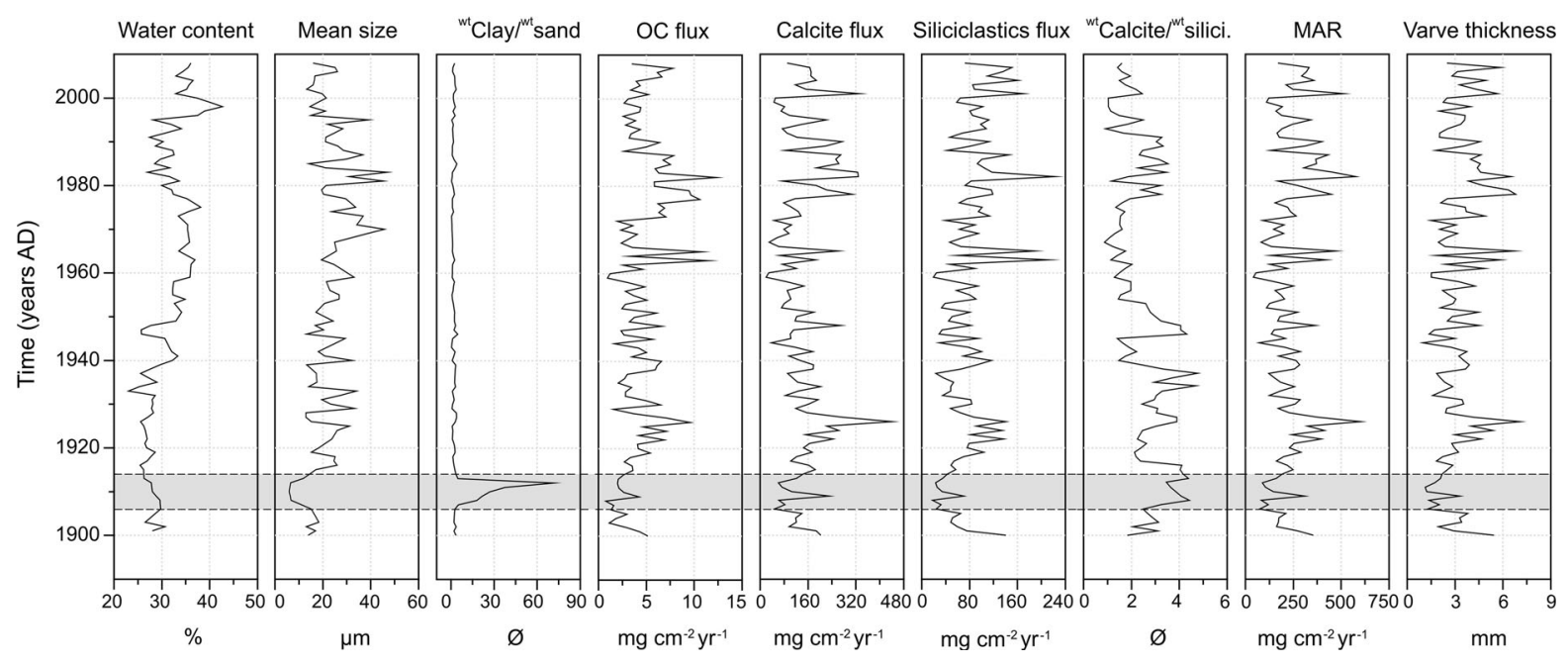

Fig. 5 Time series of proxy data of Lake Oeschinen (core OES-11). The horizontal shaded grey area highlights the zone with anomalous sediment properties

for siliciclastics can be noted. Although OC, calcite and siliciclastic particle fluxes differ in quantity, their curves show almost identical shapes and are strongly correlated with MAR $(\mathrm{r}=0.83, \quad \mathrm{r}=0.96$ and $\mathrm{r}=0.87$, respectively $p<0.01)$. Averaged MAR amounts to $232 \mathrm{mg} \mathrm{cm}^{-2}$ year $^{-1}$. Similarly, the MAR profile, derived from varve thickness, is highly correlated with this latter $(\mathrm{r}=0.89, p<0.01)$.

The shaded grey area in Fig. 5 (AD 1907-1913) highlights a part of the sediment core that is characterized by anomalies in the profiles, most clearly in the ratio of clay-sized particles to sand (values $\gg 10$ ). Additionally, the absolute lowest values in mean grain size are observed in this section $(<10 \mu \mathrm{m})$. This time interval is also marked by an increase in the ratio of ${ }^{\mathrm{wt}}$ calcite/ ${ }^{\mathrm{wt}}$ siliciclastics (maximum 3.5 ) and by low varve thicknesses (mean of $2.10 \mathrm{~mm}$ ) and MAR (158.2 $\mathrm{mg} \mathrm{cm}^{-2}$ year $^{-1}$ ).

Calibration and validation

Pearson correlation matrices reveal the best proxyclimate relationship for varve thickness as a significant $(p<0.05)$ predictor for cumulative warm season precipitation (Table 2, left panel). To explore the response sensitivity of varve thickness to seasonal precipitation, the two highest correlations are considered (MJJA and MJ). These relationships are significant for values at annual resolution $(\mathrm{r}=0.53$ and $\mathrm{r}=0.51$ respectively) and 3-year filtered resolution $(r=0.56$ and $\mathrm{r}=0.61$ respectively).
In contrast, no significant temperature signal is found in the varve thickness or any of the other proxies of Lake Oeschinen, except a weak signal for SON temperature and varve thickness $(\mathrm{r}=0.38$ at $p<0.05$ ) for 3-year triangular filtered data.

Figure $6 \mathrm{a}$ shows the calibration of 3-year filtered varve thickness data to MJJA and MJ cumulative precipitation. The calibration statistics yield $\mathrm{RMSEP}_{\text {bootstrap }}=57.8 \mathrm{~mm}$ for cumulative MJJA precipitation (32.7 mm for cumulative MJ precipitation).

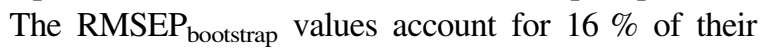
respective peak-to-peak amplitudes and for $10-13 \%$ of the mean cumulative precipitation.

The 21-year moving correlation between rainfall and varve thickness shows two distinct time-related patterns (Fig. 6b): positive correlations from AD 1916 onwards and negative correlations until AD 1915. Before AD 1915, the correlation between varve thickness and summer temperature appears to be positive and significant (up to $\mathrm{r}=0.5, p<0.05$; vertical shading in Fig. 6), and the proxy data show anomalies (horizontal shading in Fig. 5).

\section{Discussion}

Sedimentation processes

We combine surface and sediment trap samples to interpret the varve formation processes. We use the following principles: (1) the mineralogical composition 
Table 2 Left panel: Pearson correlation coefficients between seasonal climate variables and varve thickness for raw data $(1900-2009 ; \mathrm{n}=110)$ and 3-year filtered data $(1901-2008 ; \mathrm{n}=108)$, as well as for MAR at 3-year filtered data $(* p<0.05)$. Right panel: correlation coefficients reported from the study of Leemann and Niessen (1994) and varve thickness record from our study compared with annual precipitation and summer (JJAS) temperature recorded in Adelboden (11 km western Lake Oeschinen)

\begin{tabular}{|c|c|c|c|c|c|}
\hline \multirow[t]{2}{*}{ Precipitation } & \multicolumn{2}{|c|}{ Varve thickness } & \multirow{2}{*}{$\begin{array}{l}\text { MAR } \\
\text { 3-year filter }\end{array}$} & \multirow[t]{2}{*}{ Precipitation } & \multirow{2}{*}{$\begin{array}{l}\text { 1962-1982 } \\
\text { Annual Adelboder }\end{array}$} \\
\hline & Raw data & 3-year filter & & & \\
\hline SON & 0.04 & 0.26 & 0.13 & Leemann and Niessen (1994) & 0.07 \\
\hline DJF & 0.13 & 0.27 & 0.22 & & \\
\hline MAM & 0.34 & $0.51 *$ & $0.51 *$ & & \\
\hline JJA & $0.46^{*}$ & $0.45^{*}$ & $0.37 *$ & This study & 0.34 \\
\hline MJJA & $0.53 *$ & $0.56^{*}$ & $0.49 *$ & & \\
\hline MJ & $0.51 *$ & $0.62 *$ & $0.58 *$ & & \\
\hline Temperature & & & & Temperature & $\begin{array}{l}\text { 1962-1982 } \\
\text { JJAS Adelboden }\end{array}$ \\
\hline SON & 0.19 & $0.38 *$ & $0.40^{*}$ & Leemann and Niessen (1994) & $0.45 *$ \\
\hline DJF & 0.15 & 0.26 & 0.25 & & \\
\hline MAM & 0.01 & 0.05 & 0.03 & This study & 0.11 \\
\hline JJA & -0.03 & 0.17 & 0.17 & & \\
\hline
\end{tabular}

is diagnostic of the source areas and, in consequence of the erosion process (snowmelt and glacial abrasion in the glaciated southern limestone watershed; snowmelt and water erosion in the non-glaciated northern Flysch watershed); (2) the sediment grain size is diagnostic for the kinetic energy in the lake and thus for the season of deposition (large grains settle during summer when undercurrents are active and wind mixing strong; small particles settle during winter under ice-covered calm conditions); (3) the sediment mass accumulation is indicative of the intensity of the transport and settling processes. Accordingly, varve formation can be generalized in three phases.

The highest sedimentation rates observed in alpine spring (May-June; Fig. 2a, b) are likely due to a combination of snowmelt and rainfall in the catchment. This forms a basal sand layer. The mineralogical composition of these sediments suggests that particles are transported from all three parts of the catchment (Fig. 2c; Table 1). Particularly substantial is the influence of the northern Flysch catchment which is enriched in dark phyllosilicates (illite, chlorite).

In summer, the high erosivity of rainstorms and active undercurrents related to creek discharge play a major role. They transport large proportions of sand directly to the coring site close to the centre of the lake. These individual rainstorms are also suggested to form the micro-laminations found in the varves of Type III (Fig. 3). Abundant dark phyllosilicate minerals indicate that particles are mainly eroded from the northern Flysch units. The importance of undercurrents in summer has also been reported for Lake Oeschinen by Leemann and Niessen (1994).

In winter, clay-size light calcite particles settle through the water column under very calm conditions, when the lake is frozen. These fine particles are produced by glacier abrasion on the calcareous bedrock and transported by meltwater into the lake during the entire ice-free season. In summer, however, these fine particles remain in suspension. Leemann and Niessen (1994) measured average concentrations of $5.0 \mathrm{mg} \mathrm{L}^{-1}$ suspended sediments in the water column in summer 1991.

In summary, an individual varve comprises one dark spring/summer layer, sometimes multiple dark summer event layers (varves Type III) and one light winter lamina. It is mainly the summer layer that differs in the three varve types of the core. It was not possible to identify significant hydrometeorological controls over interannual accumulation variability of these three varve types (Lamoureux 2000). This is mainly due to the non presence of a hydrometric station directly at the outflow of the lake catchment and to varve counting uncertainties through the cores. 
Fig. 6 a Comparison between MJJA, MJ instrumental rainfall data (red lines) and predicted rainfall from varve thickness (black line represents the mean; grey area represents the $95 \%$ confidence envelope); b running correlations (21-year moving windows) of MJJA, MJ rainfall and maximum temperature with varve thickness; $\mathbf{c}$ distribution of Type I-III varves;

d cumulative length changes of Glacier Gamchi (km).

The vertical dark grey area refers to the period with cold summers and anomalous varves (enhanced temperature signal), the light grey vertical area shows the calibration period (AD 1962-1982) used by Leemann and Niessen (1994)

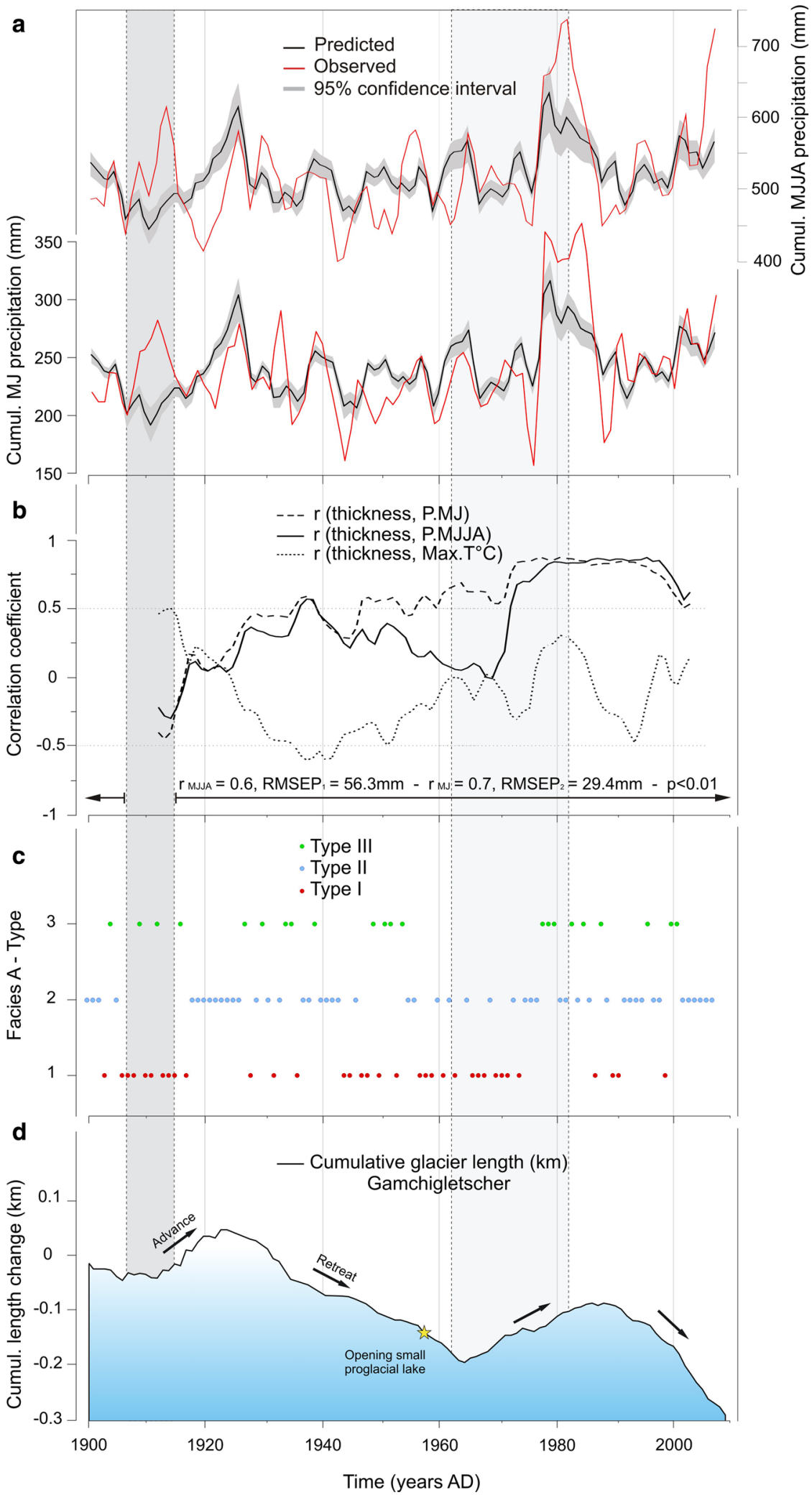


It is well established that rainfall can exert a discernible influence on annual MAR through erosion (Ohlendorf et al. 1997). Although deposition rates can vary substantially, both spatially and temporally (Schiefer and Gilbert 2008), all trends and conclusions concerning the formation of the varves in Lake Oeschinen closely agree. Leemann and Niessen (1994) similarly suggested that varve formation is directly controlled by sediment inputs from catchment inflows, which increase in quantity and grain size during the early season.

However, a disagreement remains between Leemann and Niessen (1994) and this study concerning the nature of the climate variable that influences the varve formation in Lake Oeschinen. Because no hydrometric station was present at the lake, Leemann and Niessen (1994) used the relationship between summer temperature and suspension load of river Lonza (Lötschen valley, $11 \mathrm{~km}$ southeast of Lake Oeschinen) to explain, by analogy, the sedimentation principle in Lake Oeschinen. Supported by the results shown in Figs. 2a, b (precipitation-driven system), we rejected this hypothesis. We attributed several reasons for this rejection: (1) Lötschental is an inner-Alpine valley with a markedly different hydroclimatic regime to Lake Oeschinen; (2) the catchment area of the Lonza river is approximately three times more vast than the one of Oeschinen; (3) geological settings differ remarkably where no easily erodible Tertiary Flysch are found in the Lötschen valley; (4) the glacier cover is much more extended and therefore not comparable. Nevertheless, the control of inter-annual variations of sedimentation by rainfall needs to be validated by the calibration-in-time approach.

\section{Chronology}

In quantitative paleoclimate research, it is crucial to establish a reliable chronology when aiming for highresolution reconstructions. This is provided in Lake Oeschinen by two cores which were dated with multiple independent varve counts (two analysts). From core OES-07, thirty ${ }^{210} \mathrm{~Pb}$ dates were obtained which are consistent with the ${ }^{137} \mathrm{Cs}$ peaks. Core OES11 presents relatively low varve counting errors (6-10\%) as compared to other varve sediment studies (Ojala et al. 2012) and the chronology was verified by six flood layers of known age. Moreover, the comparison of the different dating methods in these two cores shows a high degree of reproducibility, which strengthens both chronologies and increases their robustness. For obvious reasons, reproduction of chronologies is not often found in lake sediment research while it remains a standard practice in other disciplines (tree ring research, Hughes 2002).

Varve thickness as a proxy for spring and springsummer rainfall

\section{Proxy selection}

The proxy-climate correlation matrix reveals the strongest climate signal for varve thickness as a predictor for warm season rainfall. The mechanistic relation between rainfall, erosion, sediment transport, and mass accumulation is widely recognized and well understood (Tiljander et al. 2003). Moreover, our sediment trap data (Fig. 2a) show that the response of sediment accumulation to weather (snowmelt and precipitation) is immediate and thus suitable to address variability at interseasonal and annual resolution. This is in line with previous studies in Lake Oeschinen (Leemann and Niessen 1994) and sediment trap data from Lake Silvaplana, eastern Swiss Alps (Blass et al. 2007a).

The sediment water content may substantially affect the annual sediment accumulation measured as varve thickness, which means MAR should be used in preference (Elbert et al. 2012). In Lake Oeschinen, water content varies only within a small range to the extent that varve thickness and MAR are highly correlated ( $r=0.89$; Fig. 5). Moreover varve thickness can be measured from thin sections directly and much more precisely (at annual resolution and with multiple measurements) than MAR which requires sediment subsampling. Since the varves cannot be precisely cut year by year (near-annual at best) for the analysis of MAR, sampling errors are introduced to the MAR data. In our data, the MAR-climate correlation tests present systematically a weaker signal (e.g. $\left.\mathrm{r}_{(\mathrm{MAR}, \text { P.MJ }}\right)=0.58$, $p<0.05$; Table 2) than for varve thickness. For these reasons varve thickness was used in the analyses.

\section{Proxy-climate relationship}

Figures 5, 6 indicate the proxy-climate relationship may be time-dependent and different for the time before and after 1915 . 
For the period 1916-2008, the moving correlations (Fig. 6b) and the calibration statistics strongly suggest that varve thickness in Lake Oeschinen is primarily and significantly driven by cumulative summer rainfall. Further testing revealed that neither residuals from the varve thickness-rainfall relationship nor any of the other proxies indicate a temperature signal during this period. This, at the first glance, contrasts Leemann and Niessen (1994) who concluded that varve thickness from AD 1962-1982 in Lake Oeschinen (light shaded area in Fig. 6) primarily contains a summer temperature signal. This different interpretation can be attributed to three reasons: (1) Leemann and Niessen (1994) used annual precipitation data from Adelboden $(1,320 \mathrm{~m}$ a.s.l., $13 \mathrm{~km}$ western Lake Oeschinen), while we used summer precipitation data from nearby Kandersteg; (2) Leemann and Niessen (1994) noted a strong covariance between precipitation and rainfall in their data; and (3) the period of their investigation (AD 1962-1982) was rather short and appears in the running correlations of Fig. $6 \mathrm{~b}$ as a phase with a relatively increasing temperature signal and a weaker precipitation signal. To test the influence of this last point, our varve record was compared to the 1962-1982 meteorological data from Adelboden (JJAS temperature and annual precipitation; Leemann and Niessen 1994). Our varve record performs barely with both variables (Table 2, right panel) implying that other issues have to be considered for the differed interpretations: (1) the critical point of the site specificity (Schiefer and Gilbert 2008); Leemann and Niessen (1994) found that varve thickness in different parts of Lake Oeschinen varied between 0.2 and $1 \mathrm{~cm},(2)$ the uncertainties in the varve counting may significantly affect the calibration models, especially at the annual resolution (maximum counting error \pm 3 years in the period 1962-1982, Fig. 4b). This could question the reliability and reproducibility of the varve-meteorology sedimentary records.

Indeed, sedimentation rates in many proglacial lakes are known to be controlled by temperature (Trachsel et al. 2012), but this does not seem to be the case in Lake Oeschinen. The mineralogical composition of the sediments at the coring sites (OES-07 and OES-11) suggest that sediment transport from the glaciated areas is limited and subordinate in comparison to easily erodible material from the Flysch areas, which is sensitive to precipitation.

Interestingly in the period 1901-1915, the correlation between varve thickness and precipitation disappears and a positive correlation with maximum temperature is established (Fig. 6b). This part of the core is characterized by extremely high proportions of clay-sized particles compared to sand $\left({ }^{\mathrm{wt}} \mathrm{clay} /{ }^{\mathrm{wt}}\right.$ sand $>10$ ), an increase in the ratio between calcite and siliciclastic material, small grain sizes $(<10 \mu \mathrm{m})$ and low varve thickness (Fig. 5). Ohlendorf et al. (1997) and Blass et al. (2007a) similarly recorded an abnormal decrease in the MAR in the sediment of proglacial Lake Silvaplana (Engadine region, eastern Swiss Alps) at this time which coincides with a cold anomaly during the summer months (AD 1906-1925, MeteoSwiss). This cold anomaly resulted in considerable expansions of most glaciers in the Alps (Glaciological reports 1881-2009; Fig. 6d).

In Lake Oeschinen, the lack of a strong precipitation signal in the varve thickness during very cold periods may be explained by its altitude. Since the catchment of the lake is situated 500-1,500 m above the altitude of the meteorological station, precipitation recorded as rainfall in Kandersteg might have fallen as snow in the high alpine catchment. While snowfall is much less erosive, the length of the period with erosion from rainfall in summer is also reduced during cold periods (Menounos and Clague 2008). This rain/ snow threshold in turn leads to very small sedimentation rates, small mean grain size, and reduces flux of siliciclastic material from the Flysch watershed while glacial abrasion from the limestone watershed continues. This leads to varves that are relatively enriched in calcite. Fig. 5 shows high values of the ${ }^{\mathrm{wt}}$ calcite $/{ }^{\mathrm{wt}}$ siliciclastic ratio $(>3)$ during this cold phase AD 1907-1913. From these varves (Fig. 5), we can derive two objective criteria $\left({ }^{\mathrm{wt}}\right.$ clay $/{ }^{\mathrm{wt}}$ sand ratios $>10$, mean grain size $<10 \mu \mathrm{m}$; additionally high ${ }^{\mathrm{wt}}$ calcite $/{ }^{\mathrm{wt}}$ siliciclastic ratios and thin varves) for periods when varve thickness does not contain a summer rainfall signal and for which the calibration is not valid. If these years (or varves) are removed from the calibration period, MJJA precipitation from varve thickness improves by about $8 \% \quad(\mathrm{r}=0.60$, $\mathrm{RMSEP}_{\text {bootstrap }}=56.3 \mathrm{~mm}$ ) and MJ precipitation by $13 \%\left(\mathrm{r}=0.71, \mathrm{RMSEP}_{\text {bootstrap }}=29.4 \mathrm{~mm}\right)$. Both are highly significant $(p<0.01)$.

Several studies have demonstrated the complex responses of lacustrine sedimentation to a range of climate variables and other factors (Cockburn and Lamoureux 2007; Hodder et al. 2007; Kaufman et al. 2011). In most cases proxies are more likely 
influenced by a combination of several variables (temperature, precipitation, glacier melting, non-climatic and stochastic effects) rather than a single climate variable. In our case summer precipitation explains about $40 \%$ of the variance but not more. Moreover the moving proxy-climate correlations in Lake Oeschinen (Fig. 6b) show that the relative influence of precipitation and temperature changes through time, which poses a serious problem for single-variable climate reconstructions. However, the challenge is that many applications in climate research such as data-data comparisons (Trachsel et al. 2012), data-model comparisons or proxy-data assimilation in climate model simulations (Goosse et al. 2012) require time series for a single variable and a specific season of the year.

In the case of Lake Oeschinen, this problem may be addressed using additional independent sediment proxies. It appears from Figs. 5 and 6 that mean grain size is very small $(<10 \mu \mathrm{m})$ and ${ }^{\mathrm{wt}}$ clay $/{ }^{\mathrm{wt}}$ sand ratios very high $(>10)$ for the times when the relationship between the varve thickness and precipitation is weak and the influence of temperature becomes important (shaded area Fig. 6). Such objective criteria may help assessing the quality and reliability of climate reconstructions and underpin the value of multi-proxy data sets.

Influence of glacial fluctuations on sedimentation

Glacier fluctuations are known to influence sediment supply into proglacial lakes (Leonard 1997; Jansson et al. 2005, Nussbaumer et al. 2011) and thus modify MAR, varve thickness and structure (Blass et al. 2003). This is the reason why many climate reconstructions from proglacial sediments need to be detrended to account for the effect of glacier length variations (Blass et al. 2007b; Elbert et al. 2012; Trachsel et al. 2012). Blass et al. (2007a) further demonstrated that the 20th century can substantially differ from previous centuries, which questions the extension of the statistical relationships beyond the calibration period.

Accordingly, the $30 \%$ glacier cover in the catchment of Lake Oeschinen might set similar limitations. This does not seem to be the case because (1) the calibration model with the original (not detrended) varve thickness data shows robust results despite large changes in glacier length variations during the 20th century (Gamchi Glacier; Fig. 6d; note: precipitation does not show a trend in the same period); (2) the mineral mixing ratios in the sediments suggest that sediment flux and varve thickness is dominated by sediments from the non-glaciated Flysch watershed and thus largely independent of glacial erosion, and (iii) the formation of the small lake (Fig. 1a) acting as a sediment trap in front of the Bluemlisalp Glacier from ca. 1950 onwards did not lead to a systematic shift of the varve thickness in Lake Oeschinen. Thus the varve thickness-precipitation calibration in this case seems to be robust and not influenced by glaciers in the catchment. This finding is important with regard to the precipitation reconstruction pre-1901 glacier fluctuations.

\section{Conclusions}

We investigated delta-fan surface samples, sediment trap data, two well-dated short sediment cores and hydro-geological catchment properties of proglacial Lake Oeschinen (Swiss Alps) with the aim (1) to understand varve formation processes and (2) to explore the potential of the varved sediments for quantitative high-resolution climate reconstructions. For the proxy-climate calibration we used sediments and local meteorologiocal data for the period $\mathrm{AD}$ 1901-2008.

We conclude on the varve formation process from the mineralogical composition and grain size distribution of the individual sediment laminae. A coarsegrained dark basal layer enriched in siliciclastic minerals is formed during spring snowmelt and summer rainfall whereas the bright, fine-grained thin calcite layer is formed during winter under calm conditions when the lake is frozen. Radiometric dating and flood chronomarkers of known age support the annual nature of the laminae couplets (clastic varves). This forms the basis for a highly accurate and precise chronology for the proxy-climate calibration $\mathrm{AD}$ 1901-2008.

We conclude from the proxy-climate correlation matrix that varve thickness best contains the climate signal and explains $40-50 \%$ of the variance of summer precipitation $\quad\left(\mathrm{r}_{\mathrm{MJJA}}=0.6, \quad \mathrm{r}_{\mathrm{MJ}}=0.7\right.$, $p<0.01)$. Varves in rainy summers show higher sediment fluxes, greater thickness and are enriched with siliciclastic minerals from the sub-watershed 
characterized by Flysch bedrock and easily erodible material. Varve thickness does not seem to be influenced by length variations of glaciers in the catchment.

We find that the relationship between varve thickness and summer precipitation is not stable for periods with very cold summers as observed between AD 1901 and 1915. Thus we develop objective criteria ( ${ }^{\mathrm{wt}}$ clay $/{ }^{\mathrm{wt}}$ sand ratios $>10$, mean grain size $<10 \mu \mathrm{m}$ ) to identify sediment sections where the proxy-climate calibration model should not be applied.

According to our results, the varved sediments of Lake Oeschinen hold great potential for investigating past precipitation variations and changes in the coupled lake-catchment system beyond the instrumental period.

Acknowledgments We thank Mr Hirschi for granting access to Lake Oeschinen, Richard Niederreiter for help with the freeze coring, and Urs Eggenberger (Institute of Geological Sciences, University of Bern) for assistance with XRD. The help and expertise of Samuel Hagnauer and Daniela Fischer was particularly essential from the field to the lab. Thanks to Mathias Trachsel and Christian Kamenik for statistical discussions, and Krystyna Saunders for comments on this manuscript. This work is funded through the Swiss National Science Foundation 200020-134945.

\section{References}

Appleby PG (2001) Chronostratigraphic techniques in recent sediments. In: Last WM, Smol JP (eds) Tracking environmental change using lake sediments: basin analysis, coring, and chronological techniques. Kluwer, Dordrecht, pp 171-201

Arnaud F, Lignier V, Revel M, Desmet M, Beck C, Pourchet M, Charlet F, Trente-Saux A, Tribovillard N (2002) Flood and earthquake disturbance of ${ }^{210} \mathrm{~Pb}$ geochronology (Lake Anterne, NW Alps). Terra Nova 14:225-232

Birks HJB (2005) Overview of numerical methods in palaeolimnology. In: Birks HJB, Lotter AF, Juggins S (eds) Tracking environmental change using lake sediments: data handling and numerical techniques. Kluwer, Dordrecht, pp 19-92

Blass A, Anselmetti FS, Ariztegui D (2003) 60 years of glaciolacustrine sedimentation in Steinsee (Sustenpass, Switzerland) compared with historic events and instrumental meteorological data. Eclogae Geol Helv 96(1):59-71

Blass A, Grosjean M, Troxler A, Sturm M (2007a) How stable are twentieth-century calibration models? A high-resolution summer temperature reconstruction for the eastern Swiss Alps back to AD 1580 derived from proglacial varved sediments. Holocene 17:51-63

Blass A, Bigler C, Grosjean M, Sturm M (2007b) Decadal-scale autumn temperature reconstruction back to $\mathrm{AD} 1580$ inferred from the varved sediments of Lake Silvaplana (south-eastern Swiss Alps). Quat Res 68:184-195

Brunetti M, Maugeri M, Nanni T, Auer I, Böhm R, Schöner W (2006) Precipitation variability and changes in the greater Alpine region over the 1800-2003 period. J Geophys Res 111:1-29

Büntgen U, Tegel W, Nicolussi K, McCormick M, Frank D, Trouet V, Kaplan JO, Herzig F, Heussner KU, Wanner H, Luterbacher J, Esper J (2011) 2500 years of European climate variability and human susceptibility. Science 331:578-582

Casty C, Wanner H, Luterbacher J, Esper J, Böhm R (2005) Temperature and precipitation variability in the European Alps since 1500. Int J Clim 25:1855-1880

Cockburn JMH, Lamoureux SF (2007) Century-scale variability in late-summer rainfall events recorded over seven centuries in sub annually laminated lacustrine sediments, White Pass, British Columbia. Quat Res 67:193-203

de Jong R, Kamenik C (2011) Validation of a chrysophyte stomatocyst-based cold-season climate reconstruction from high Alpine Lake Silvaplana, Switzerland. J Quat Sci 26:268-275

Elbert J, Grosjean M, von Gunten L, Urrutia R, Fischer D, Wartenburger R, Ariztegui D, Fujak M, Hamann Y (2012) Quantitative high-resolution winter (JJA) precipitation reconstruction from varved sediments of Lago Plomo $47^{\circ} \mathrm{S}$, Patagonian Andes, AD 1530-2002. Holocene 22:465-474

Glaciological reports, 1881-2009. The Swiss glaciers, yearbooks of the cryospheric Commission of the Swiss Academy of Sciences (SCNAT) published since 1964 by the Labratory of Hydraulics, Hydrology and Glaciology (VAW) of ETH Zurich. No. 1-126, (http://glaciology.ethz. ch/swiss-glaciers/)

Goosse H, Guiot J, Mann ME, Dubinkina S, Sallaz-Damaz Y (2012) The medieval climate anomaly in Europe: comparison of the summer and annual mean signals in two reconstructions and in simulations with data assimilation. Glob Planet Ch 84-85:35-47

Hegerl GC, Crowley TJ, Hyde WT, Frame DJ (2006) Climate sensitivity constrained by temperature reconstructions over the past seven centuries. Nature 440:1029-1032

Heiri O, Lotter AF, Lemcke G (2001) Loss on ignition as a method for estimating organic and carbonate content in sediments: reproducibility and comparability of results. J Paleolimnol 25:101-110

Hodder KR, Gilbert R, Desloges JR (2007) Glaciolacustrine varved sediment as an alpine hydroclimatic proxy. J Paleolimnol 38:365-394

Hughen KA, Overpeck JT, Anderson RF (2000) Recent warming in a 500-year palaeotemperature record from varved sediments, Upper Soper Lake, Baffin Island, Canada. Holocene 10:9-19

Hughes MK (2002) Dendrochronology in climatology-the state of the art. Dendrochronologia 20:95-116

Jansson P, Rosqvist G, Schneider T (2005) Glacier fluctuations, suspended sediment flux and glacio-lacustrine sediments. Geogr Ann A 87:37-50

Kalugin I, Daryin A, Smolyaninova L, Andreev A, Diekmann B, Khlystov O (2007) 800-year-long records of annual air temperature and precipitation over southern Siberia inferred from Teletskoye Lake sediments. Quat Res 67:400-410 
Kamenik C, van der Knaap WO, van Leeuwen JFN, Goslar T (2009) Pollen/climate calibration based on a near-annual peat sequence from the Swiss Alps. J Quat Sci 24:529-546

Kaufman CA, Lamoureux SF, Kaufman DS (2011) Long-term river discharge and multidecadal climate variability inferred from varved sediments, southwest Alaska. Quat Res 76:1-9

Lamoureux SF (2000) Five centuries of interannual sediment yield and rainfall-induced erosion in the Canadian High Arctic recorded in lacustrine varves. Water Resour Res 36:309-318

Lamoureux SF (2001) Varve chronology techniques. In: Last WM, Smol JP (eds) Tracking environmental change using lake sediments: basin analysis, coring, and chronological techniques. Kluwer, Dordrecht, pp 247-260

Larocque-Tobler I, Grosjean M, Heiri O, Trachsel M, Kamenik C (2010) Thousand years of climate change reconstructed from chironomid subfossils preserved in varved lake Silvaplana, Engadine, Switzerland. Quat Sci Rev 29:1940-1949

Larocque-Tobler I, Quinlan R, Stewart MM, Grosjean M (2011) Chironomid-inferred temperature changes of the last century in anoxic Seebergsee, Switzerland: assessment of two calibration methods. Quat Sci Rev 30:1770-1779

Leemann A, Niessen F (1994) Varve formation and the climatic record in an Alpine proglacial lake: calibrating annually laminated sediments against hydrological and meteorological data. Holocene 4:1-8

Leonard EM (1997) The relationship between glacial activity and sediment production: evidence from a 4450-year varve record of neoglacial sedimentation in Hector Lake, Alberta, Canada. J Paleolimnol 17:319-330

Mann ME, Zhang Z, Hughes MK, Bradley RS, Miller SK, Rutherford S, Ni F (2008) Proxy-based reconstructions of hemispheric and global surface temperature variations over the past two millennia. Proc Natl Acad Sci USA 105:13252-13257

McKay NP, Kaufman DS, Michelutti N (2008) Biogenic silica concentration as a high-resolution, quantitative temperature proxy at Hallet Lake, south-central Alaska. Geophys Res Lett 35:L05709

Menounos B, Clague JJ (2008) Reconstructing hydro-climatic events and glacier fluctuations over the past millennium from annually laminated sediments of Cheakamus Lake, southern Coast Mountains, British Columbia, Canada. Quat Sci Rev 27:701-713

Meyer MC, Faber R, Spotl C (2006) The wingeol lamination tool: new software for rapid, semi-automated analysis of laminated climate archives. Holocene 16:753-761

Mitchell TD, Jones PD (2005) An improved method of constructing a database of monthly climate observations and associated high-resolution grids. Int J Climatol 25:693-712

Moore JJ, Hughen KA, Miller GH, Overpeck JT (2001) Little Ice Age recorded in summer temperature reconstruction from varved sediments of Donard Lake, Baffin Island, Canada. J Paleolimnol 25:503-517

Niessen F, Wick L, Bonani G, Chondrogianni C, Siegenthaler C (1992) Aquatic system response to climatic and human changes: productivity, bottom water oxygen status, and sapropel formation in Lake Lugano over the last 10,000 years. Aqua Sci 54:257-276
Niklaus M (1967) Geomorphologische und limnologische Untersuchungen am Öschinensee. $\mathrm{PhD}$ thesis. Kümmerly und Frey, Bern

Nussbaumer SU, Steinhilber F, Trachsel M, Breitenmoser P, Beer J, Blass A, Grosjean M, Hafner A, Holzhauser H, Wanner H, Zumbuehl HJ (2011) Alpine climate during the Holocene: a comparison between records of glaciers, lake sediments and solar activity. J Quat Sci 26:703-713

Ohlendorf C, Niessen F, Weissert H (1997) Glacial varve thickness and 127 years of instrumental climate data: a comparison. Clim Change 36:391-411

Ojala AEK, Francus P, Zolitschka B, Besonen M, Lamoureux SF (2012) Characteristics of sedimentary varve chronologies-a review. Quat Sci Rev 43:45-60

PAGES 2 k Consortium (2013) Continental-scale temperature variability during the last two millennia. Nat Geosci $6: 339-346$

Pauling A, Luterbacher J, Casty C, Wanner H (2006) Five hundred years of gridded high-resolution precipitation reconstructions over Europe and the connection to largescale circulation. Clim Dynamic 26:387-405

Pfister C (1999) Wetternachhersage: 500 Jahre Klimavariationen und Naturkatastrophen (1496-1995). Verlag Paul Haupt, Bern

Pienitz R, Lotter A (2009) Editorial: advances in paleolimnology. In: Pienitz R, Lotter A, Newman L, Kiefer T (eds) Advances in paleolimnology. PAGES News 17 (3): 89-136

Saunders KM, Grosjean M, Hodgson DA (2013) A 950 year temperature reconstruction from Duckhole Lake, southern Tasmania, Australia. Holocene 23:771-783

Schiefer E, Gilbert R (2008) Proglacial sediment trapping in recently formed Silt Lake, Upper Lillooet Valley, Coast Mountains, British Columbia. Earth Surf Proc Land 33:1542-1556

Schmocker-Fackel P, Naef F (2010) More frequent flooding? Changes in flood frequency in Switzerland since 1850. J Hydrol 381:1-8

Stewart M, Larocque-Tobler I, Grosjean M (2011) Quantitative inter-annual and decadal June-July-August temperature variability ca. $570 \mathrm{BC}$ to AD 120 (Iron Age-Roman Period) reconstructed from the varved sediments of Lake Silvaplana. Switz J Quat Sci 26:491-501

Suchy V, Frey M, Wolf M (1997) Vitrinite reflectance and shear-induced graphitization in orogenic belts: a case study from the Kandersteg area, Helvetic Alps, Switzerland. Int J Coal Geol 34:1-20

Tiljander M, Saarnisto M, Ojala AEK, Saarinen T (2003) A 3,000-year palaeoenvironmental record from annually laminated sediment of Lake Korttajärvi, central Finland. Boreas 26:566-577

Trachsel M, Eggenberger U, Grosjean M, Blass A, Sturm M (2008) Mineralogy-based quantitative precipitation and temperature reconstructions from annually laminated lake sediments (Swiss Alps) since AD 1580. Geophy Res Lett 35:L13707

Trachsel M, Grosjean M, Schnyder D, Kamenik C, Rein B (2010) Scanning reflectance spectroscopy (380-730 nm): a novel method for quantitative high-resolution climate reconstructions from minerogenic lake sediments. J Paleolimnol 44:979-994 
Trachsel M, Kamenik C, Grosjean M, McCarroll D, Moberg A, Brázdil R, Büntgen U, Dobrovolný P, Esper J, Frank DC, Friedrich M, Glaser R, Larocque-Tobler I, Nicolussi K, Riemann D (2012) Multi-archive summer temperature reconstruction for the European Alps, AD 1053-1996. Quat Sci Rev 46:66-79

Villalba R, Grosjean M, Kiefer T (2009) Long-term multi-proxy climate reconstructions and dynamics in South America (LOTRED-SA): state of the art and perspectives. Palaeogeogr Palaeoclimatol Palaeoecol 281:175-179

von Gunten L, Grosjean M, Rein B, Urrutia R, Appleby P (2009) A quantitative high-resolution summer temperature reconstruction based on sedimentary pigments from Laguna Aculeo, central Chile, back to AD 850. Holocene 19:873-881

von Gunten L, Grosjean M, Kamenik C, Fujak M, Urrutia R (2012) Calibrating biogeochemical and physical climate proxies from non-varved lake sediments with meteorological data: methods and case studies. J Paleolimnol 47:583-600

Wanner H, Rickli R, Salvisberg E, Schmutz C, Schüepp M (1997) Global climate change and variability and its influence on Alpine climate-concepts and observations. Theor Appl Clim 58:221-243

Zolitschka B (1996) High resolution lacustrine sediments and their potential for palaeoclimatic reconstruction. In: Jones PD, Bradley RS, Jouzel J (eds) Climatic variations and forcing mechanisms of the last 2000 years. Springer-Verlag, Berlin, pp 453-478

Zolitschka B (2007) Varved lake sediments. In: Elias SA (ed) Encyclopedia of quaternary science. Elsevier, Amsterdam, pp 3105-3114 